\title{
Minimal invasive surgical resection of myxomas: a three case series study
}

\author{
Resección quirúrgica mínimamente invasiva de mixomas: estudio de tres casos \\ Carlos J. Pérez-Rivera*, Alejandro González-Orozco, Rafael Figueroa-Casanova, \\ Juan S. Ramírez e Isabela Caicedo-Holguín \\ Department of Cardiovascular Surgery, Clínica Avidanti, Ibagué, Colombia
}

\begin{abstract}
Introduction and Objective: Cardiac tumors are often unrecognized until autopsies are performed or diagnosed from routine studies based on unspecific symptoms. The most common type of tumor is the myxoma, although rare, upon diagnosis an urgent surgical resection is often required. Previously the ideal surgical approach was a standard median sternotomy, however recently newer surgical techniques have been employed with excellent results. We describe a recent surgical approach via the right lateral minithoracotomy as a minimally invasive intervention with three cases that evidence an appropriate and ideal surgical approach. Method and Patients: We present three cases of minimally invasive myxoma resection via the right lateral minithoracotomy. Results and discussion: In this three-case series study, no complications were reported peri-operatively nor at the 6 and 12-month follow-ups. In comparison with international literature, surgical approaches in Colombia are comparable with successful resection and little or no complications peri-operatively. Conclusions: The right lateral minithoracotomy appears to be a safe approach in myxoma resection. We hope to enhance and promote the surgical community in Colombia to opt for alternative less invasive approaches in these type of cases, to ensure excellent results and promote further research as seen in other countries.
\end{abstract}

Key words: Cardiac myxoma. Minithoracotomy. Cardiovascular surgery.

\section{Resumen}

Introducción y Objetivo: Los tumores cardíacos no suelen ser diagnosticados hasta la realización de autopsia o en otros casos como hallazgos incidentales. El tumor cardiaco más común es el mixoma, aunque es poco frecuente; en el momento del diagnóstico a menudo se requiere una resección quirúrgica urgente. Anteriormente el enfoque quirúrgico era una atriotomía abierta derecha; sin embargo, recientemente se han empleado técnicas quirúrgicas nuevas con excelentes resultados. Describimos una técnica quirúrgica reciente a través de la minitoracotomía lateral derecha como un método mínimamente invasivo con tres casos que evidencian un método quirúrgico apropiado e ideal. Métodos y pacientes: Se presentan tres casos de resección mínimamente invasiva de mixomas a través de una minitoracotomía lateral derecha. Resultados y discusión: Es estos tres casos no se reportaron complicaciones perioperatorias ni durante el seguimiento a los 6 y 12 meses. En comparación con otras series de casos en la literatura, el enfoque en Colombia ha sido comparable tanto en los resultados exitosos como con las técnicas quirúrgicas, sin complicaciones asociadas. Conclusiones: La minitoracotomía lateral derecha puede ser

\section{Correspondence:}

${ }^{\star}$ Carlos J. Pérez-Rivera

E-mail: cjperezrivera@gmail.com
Date of reception: 17-12-2019

Date of acceptance: 03-11-2020

DOI: 10.24875/RCCAR.M21000107
Available online: 07-01-2022

Rev Colomb Cardiol. 2021;28(6):642-647

www.rccardiologia.com 0120-5633 / @ 2020 Sociedad Colombiana de Cardiología y Cirugía Cardiovascular. Published by Permanyer. This is an open access article under the CC BY-NC-ND license (http://creativecommons.org/licenses/by-nc-nd/4.0/). 
considerada segura en resección de mixoma. Con este tipo de reportes se espera suscitar en la comunidad médica la elección de alternativas quirúrgicas mínimamente invasivas para garantizar excelentes resultados y promover la investigación, como se evidencia en el resto del mundo.

Palabras clave: Mixoma cardíaco. Minitoracotomía. Cirugía Cardiovascular.

\section{Introduction}

Cardiac tumors are rare and often unrecognized until autopsies are performed, before 1951 diagnosis was exclusively post-mortem ${ }^{1}$. Primary cardiac tumors are mostly benign (75\%), the most common type being myxoma in half of those cases $^{1-4}$. Although myxomas' incidence is rare $(0.001-0.1 \%)^{3-4}$, it is prevalent in all ages and appears in the left atrium in $60-85 \%$ of the cases, rarely biatrial (5\%), with an average size of $5-6 \mathrm{~cm}^{3-5}$. It is believed that myxomas arise at the cardiac septation from mesenquimal multipotent cells that persist as embryonal residues or from endocardial neural cells ${ }^{5}$.

Their clinical course varies depending on: attachment site, number of masses, comorbidities, recurrence, calcification and/or necrosis, and symptoms. Some can be completely asymptomatic $(10 \%)^{4}$, while others can have systemic symptoms $(34-90 \%)^{4-5}$ or valvular syndrome including sudden death ${ }^{6}$. A large percentage of patients debut with embolic complications $(30-50 \%)^{2-5}$.

The diagnosis is often incidental via non-invasive images such as echocardiography, computed tomography $(\mathrm{CT})$ scan, or magnetic resonance imaging $(\mathrm{MRI})^{6}$, often as a result of heart failure/angina $(67 \%)$ or constitutional symptoms (13-34 \%) ${ }^{3}$. The main diagnostical tool and follow-up is the echocardiography ${ }^{3,4,6}$, either transthoracic or transesophageal, however often more extensive images are required to characterize the tumor.

Symptomatic patients require urgent surgical resection to prevent complications ${ }^{2,3,6}$, with a postoperative mortality of 1.7-7.5 \%3, recurrence of 1-4 $\%^{3,4,6}$, and 5 -year survival rate of $83 \%{ }^{2}$. Classically, in left atrium myxomas, a standard median sternotomy with a bicaval cardiopulmonary bypass has been performed, with resection through a right atriotomy and transseptal access. Interatrial septum defect is then corrected directly or with a pericardial (PTFE or Dacron) patch ${ }^{3}$. In complex tumors, a biatrial approach is often considered.

Recently, minithoracotomy with robotic and video-assisted resection has been performed, however the risk of incomplete resection is higher. Other accessible minimally invasive surgical alternatives such as a minithoracotomy with direct vision have been applied $^{6-7}$.

\section{Cases}

It is presented three cases of minimally invasive myxoma resection via the right lateral minithoracotomy. In all three cases, diagnosis was made via echocardiography (Fig. 1). Patient one is a 59-year-old female with a $1.5 \mathrm{~cm}$ myxoma, patient two is a 74-year-old male with a $6 \times 4 \mathrm{~cm}$ myxoma (Fig. 2) and patient three is a 24-year-old female with a $3.8 \mathrm{~cm} \times 3.3 \mathrm{~cm}$ myxoma.

Under general anesthesia, previously inserting a central venous access (internal jugular right vein) and arterial line (left radial artery), patient was heparinized at a dose of $3 \mathrm{mg} / \mathrm{kg}$. The right lateral minithoracotomy incision was performed, dissection of femoral blood vessels with posterior distal and proximal repair (purse string suture with $5 / 0$ prolene in right common femoral arterial and purse string suture with $5 / 0$ prolene in right femoral vein with Seldinger technique for superior vena cava cannulation through the right jugular vein). Once the activated coagulation time was $>500 \mathrm{~ms}$, the canulation of the femoral artery was achieved with Bio-Medicus $17 \mathrm{fr}$ (patient 3)/19 fr (patient 2)/21 fr (patient 1), the femoral vein with a multiperforated cannula $25 \mathrm{fr}$, and the jugular vein with $15 \mathrm{fr}$. The MiAR cardioplegia cannula was inserted in the aortic root, then the corporal temperature was reduced to $34^{\circ} \mathrm{C}$ to ensure an adequate pinching of the aortic root and posterior infusion of the high-potassium concentration crystalloid cardioplegic solution as well as cold topic saline solution until achieving complete cardioplegia. This allowed the extracorporeal circulation to be completed without any complications.

Once the myxoma resection was completed, the left atrium is closed with a continuous sutured with prolene with previous lavage to remove any thrombi. The corporal temperature was increased to $32^{\circ} \mathrm{C}$ to uncinch the aortic root and allow reperfusion. The heart regained electrical activity with a sinus rhythm, to posteriorly suspend the extracorporeal circulation pump at $37^{\circ} \mathrm{C}$. In patient 2 , the heart regained electrical activity 
Rev Colomb Cardiol. 2021;28(6)

Table 1. Characteristics of the three patients who underwent minimally invasive myxoma resection via the right lateral minithoracotomy

\begin{tabular}{|c|c|c|c|c|c|c|c|c|c|}
\hline Patient & Gender & Age & $\begin{array}{l}\text { Location and } \\
\text { LVEF ( \%) }\end{array}$ & Size $(\mathrm{cm})$ & Symptoms & $\begin{array}{l}\text { Pump time } \\
\text { (min) }\end{array}$ & $\begin{array}{c}\text { Clamp } \\
\text { time (min) }\end{array}$ & Bleeding & $\begin{array}{l}\text { Days } \\
\text { hospitalized }\end{array}$ \\
\hline 1 & Female & 59 & $\begin{array}{l}\text { Posterior } \\
\text { interatrial } \\
\text { septum } \\
(0.9 \times 0.7 \mathrm{~cm}) \\
\text { and LVEF } 74 \%\end{array}$ & $1.5 \times 1.5$ & Presyncope & 103 & 37 & $\begin{array}{l}\text { Limited } \\
(<300 \mathrm{ml})\end{array}$ & $\begin{array}{l}\text { Pre-0p: } 10 \\
\text { ICU Post: } 6 \\
\text { Floor: } 3 \\
\text { Total: } 19\end{array}$ \\
\hline 2 & Male & 74 & $\begin{array}{l}\text { Left atrium }(4.9 x \\
4.6 \mathrm{~cm}) \text { and LVEF } \\
63 \%\end{array}$ & $6 \times 4$ & $\begin{array}{l}\text { Progressive } \\
\text { dyspnea }\end{array}$ & 90 & 45 & $\begin{array}{l}\text { Limited } \\
\text { (<300 ml) }\end{array}$ & $\begin{array}{l}\text { Pre-0p: } 6 \\
\text { ICU Post: } 2 \\
\text { Floor: } 2 \\
\text { Total: } 10\end{array}$ \\
\hline 3 & Female & 24 & $\begin{array}{l}\text { Left atrium } \\
\text { embedded in } \\
\text { septum and LVEF } \\
57 \%\end{array}$ & $3.8 \times 3.3$ & $\begin{array}{l}6 \text { months of } \\
\text { atypical } \\
\text { chest pain, } \\
\text { progressive } \\
\text { dyspnea }\end{array}$ & 91 & 44 & $\begin{array}{l}\text { Limited } \\
(<300 \mathrm{ml})\end{array}$ & $\begin{array}{l}\text { Pre-0p: } 1 \\
\text { ICU Post: } 4 \\
\text { Floor: } 1 \\
\text { Total: } 6\end{array}$ \\
\hline
\end{tabular}

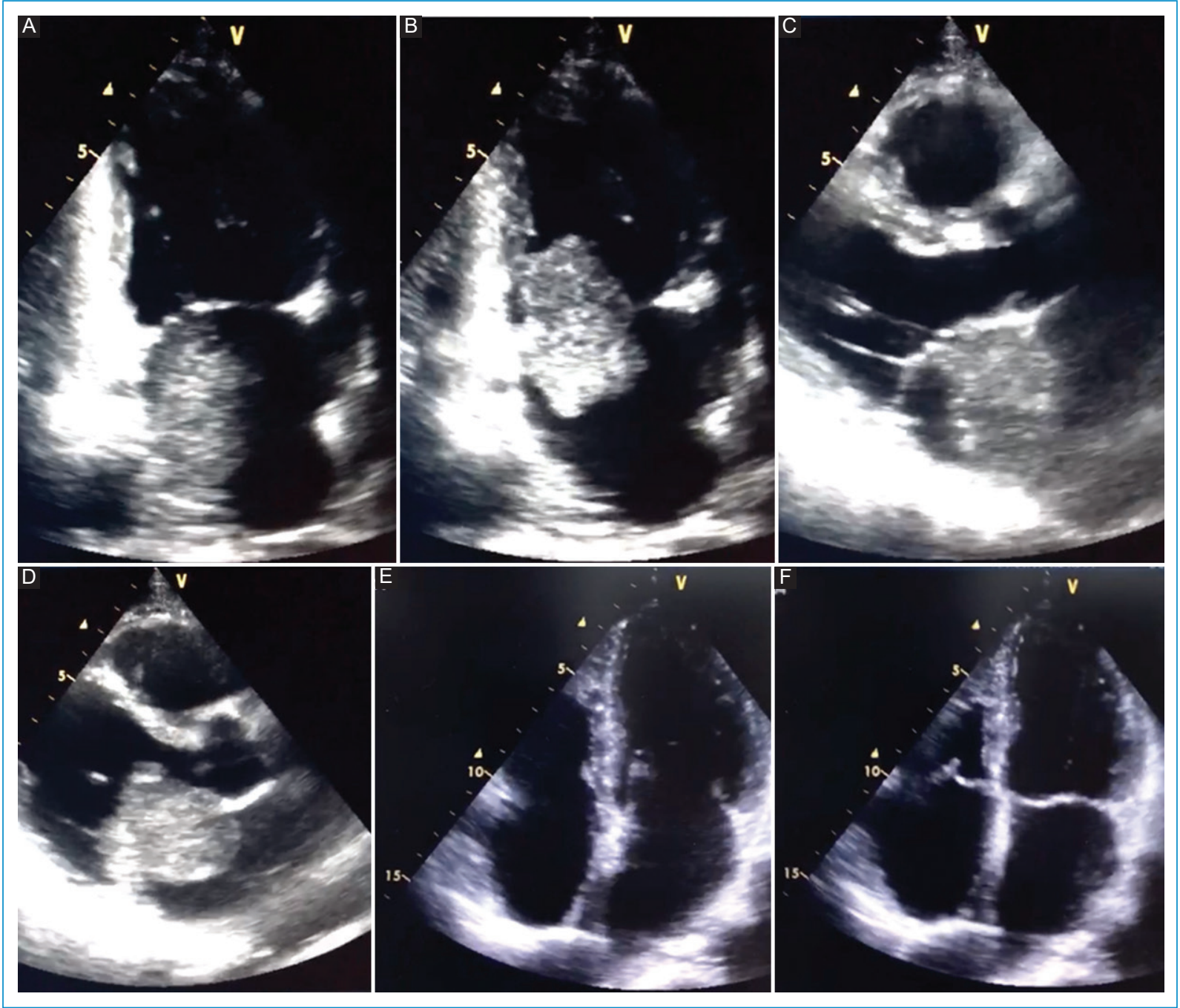

Figure 1. Echocardiography of patient 1 with the myxoma visible (A-D) as well as out-patient echocardiography posterior to resection (E-F). 
Table 2. Characteristics of other case series reported in the literature ( $n>17)$ as comparison

\begin{tabular}{|c|c|c|c|c|}
\hline Authors & Patients & Symptoms & Mortality & Complications \\
\hline Pinede et al. & 122 & $\begin{array}{l}\text { Cardiac failure signs }(43 \%) \text {. } \\
\text { Syncope }(14 \%) \text {. } \\
\text { Palpitations and thoracic pain }(30 \%) \text {. } \\
\text { Fever }(20 \%) \text {. } \\
\text { Constitutional }(18 \%) \text {. } \\
\text { Embolic events }(29 \%) \text {. }\end{array}$ & $3.5 \%$. & $\begin{array}{l}\text { Arrythmias } 29 \% \text {. } \\
\text { Recurrence (5\%). }\end{array}$ \\
\hline Barnes et al. & 18 & $\begin{array}{l}\text { Cardiac failure signs (44\%). } \\
\text { Embolic events (27\%). } \\
\text { Arrythmias }(27 \%) .\end{array}$ & $0 \%$. & Atrial fibrillation $(5 \%)$. \\
\hline Muthubaskaran et al. & 32 & $\begin{array}{l}\text { Cardiac failure signs }(47 \%) \text {. } \\
\text { Embolic events }(34 \%) \text {. } \\
\text { Constitutional }(32 \%) \text {. }\end{array}$ & $0 \%$. & $\begin{array}{l}\text { Recurrence }(6 \%) \text {. } \\
\text { Peripheral embolus }(6 \%) \text {. } \\
\text { Pulmonary embolism }(3 \%) \text {. }\end{array}$ \\
\hline Garatti et al. & 98 & $\begin{array}{l}\text { Dyspnea (68\%). } \\
\text { Palpitations ( } 38 \%) \text {. } \\
\text { Cardiac failure signs (30\%). } \\
\text { Embolic events }(35 \%) \text {. } \\
\text { Constitutional }(57 \%) .\end{array}$ & $3 \%$. & Recurrence (1\%). \\
\hline Lee et al. & 93 & $\begin{array}{l}\text { Dyspnea }(38.7 \%) \text {. } \\
\text { Thoracic pain }(21.5 \%) \text {. } \\
\text { Palpitations }(8.6 \%) \text {. } \\
\text { Embolic events }(10.8 \%) \text {. } \\
\text { Syncope }(5.4 \%) .\end{array}$ & $3.2 \%$ & Recurrence $(2.1 \%)$. \\
\hline Lin et al. & 68 & $\begin{array}{l}\text { Dyspnea }(57 \%) \text {. } \\
\text { Palpitations }(46 \%) \text {. } \\
\text { Syncope }(21 \%) \text {. } \\
\text { Cardiac failure signs (21\%). } \\
\text { Constitutional }(35 \%) \text {. } \\
\text { Embolic events }(24 \%) .\end{array}$ & $2.8 \%$ & $\begin{array}{l}\text { Pleural effusion (22\%). } \\
\text { Low output syndrome }(7 \%) \text {. } \\
\text { Atrial fibrillation }(6 \%) \text {. } \\
\text { Pericardial effusion (4\%). } \\
\text { Pneumothorax }(3 \%) . \\
\text { Pneumonia }(3 \%) \text {. } \\
\text { Respiratory failure }(1.5 \%) \text {. }\end{array}$ \\
\hline Jawad et al. & 269 & $\begin{array}{l}\text { Dyspnea }(34.9 \%) \text {. } \\
\text { Arrhythmias }(21.2 \%) \text {. } \\
\text { Embolic events }(13.4 \%) \text {. } \\
\text { Thoracic pain }(10.8 \%) \text {. }\end{array}$ & $1.9 \%$. & $\begin{array}{l}\text { Arrhythmias }(28.3 \%) \text {. } \\
\text { Syncope }(10 \%) \text {. } \\
\text { Respiratory insufficiency } \\
\text { (3.3\%). } \\
\text { Pericardial effusion }(3.3 \%) \text {. } \\
\text { Peripheral embolus }(1.1 \%) \text {. }\end{array}$ \\
\hline Gandara et al. & 18 & $\begin{array}{l}\text { Dyspnea }(35 \%) \text {. } \\
\text { Thoracic pain }(28 \%) \text {. } \\
\text { Constitutional symptoms }(20-22 \%) \text {. } \\
\text { Syncope }(14 \%) \text {. }\end{array}$ & $17 \%$. & Not reported. \\
\hline
\end{tabular}

with a ventricular fibrillation requiring $200 \mathrm{~J}$ discharge with reversion to sinus rhythm. Decannulation was then completed with suture reinforcement and once hemostasia was completed, an electrode was placed in the ventricular epicardium as well as mediastinal and pleural tubes to posteriorly close the thoracic cavity with one or two $1 / 0$ vicryl sutures, fascia with $2 / 0$ vicryl, and skin with $4 / 0$ vicryl. Coagulation time control was completed using 5 cartridges in the Automated Coagulation Timer.

\section{Results}

Resulting biopsies of all excisions confirmed complete resection of each mass as well as confirmation of a myxoma. All patients had an in-hospital stay without any complications reported, requiring ICU-stance as routine post-operatively cautionary follow-up (Table 1) and intravenous ionotropic drugs during the immediate post-op. The only slight intra-operative complication was with patient 2 whom presented ventricular fibrillation in the return of electrical activity, successfully 


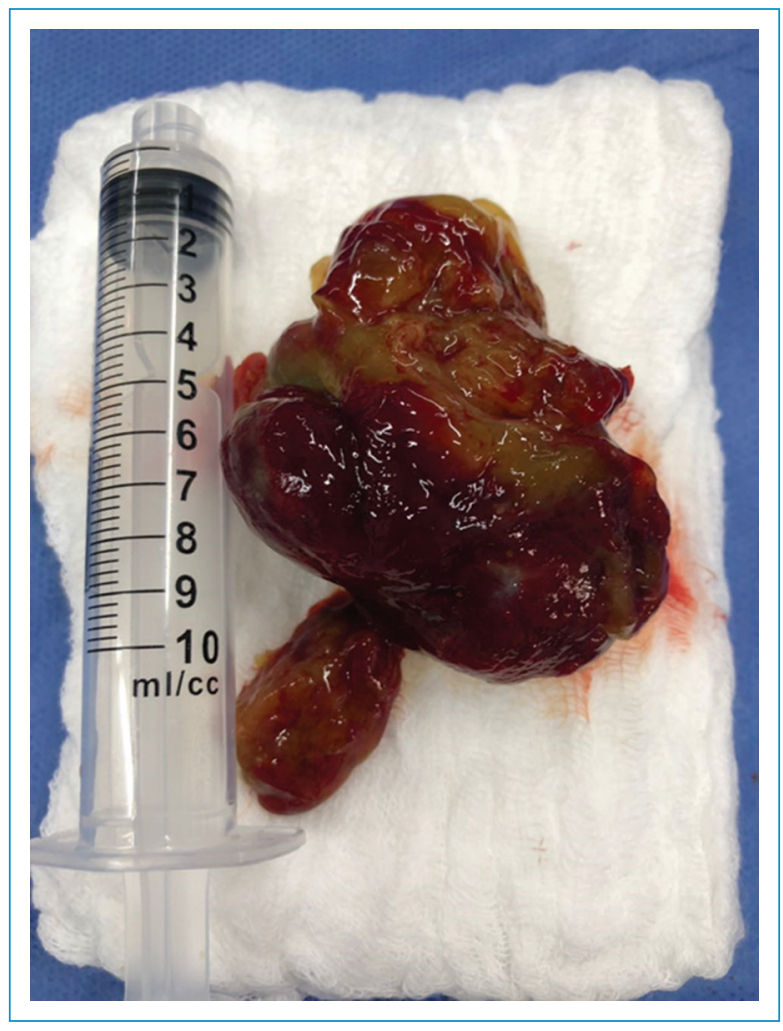

Figure 2. Resection of the intraoperative myxoma of patient 2.

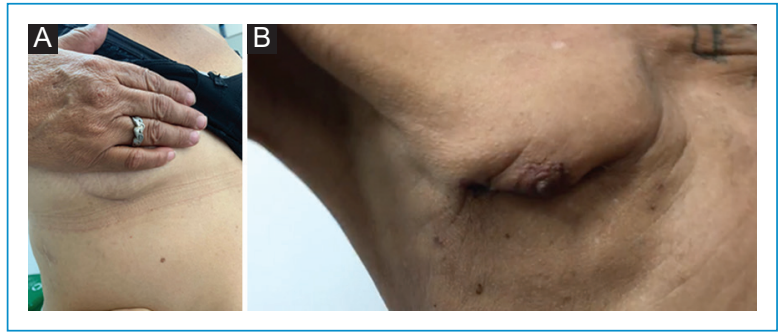

Figure 3. Scars of the right-lateral minimally invasive approach in the out-patient follow up. A: patient 1. B: patient 2.

reverted with one electrical discharge. In the out-patient follow-up, patients one and two had minimal scars post-surgically (Fig. 3). All interventions were performed successfully without any peri-operative complications or mortalities, with ICU stay Quality of life scale (SF-36) was applied 6 and 12 months postoperatively with scores above $90 \%$. Additionally, patient 1 had echocardiography immediately, 2 months and 28 months postoperatively; patient 2 had echocardiography at 1 month and 8 months postoperatively; patient 3 at 1 month and 16 months postoperatively; all reports with a conserved ejection fraction and without any masses visible.

\section{Discussion}

Compared to other cases series in the literature, reports in our study were consistent in the average clinical course. Although a small sample size, all three were diagnosed via echocardiography and none reported any complications or mortality peri-operatively. We describe the most relevant findings (Table 1), while comparing worldwide similar case series reports $(n>17)$ albeit with a much larger sample size (Table 2). In this setting, our cases represent similar findings with respect to symptoms, bleeding, and peri-operative morbidity and mortality. Although other cases series usually do not report pump and clamp time, our time settings are within range of averages reported in other literature, as well as myxoma size and location ${ }^{3-5}$. Unfortunately given that in the three cases the in-hospital stay was very variable, we cannot ensure this as an advantage, a larger sample size is required.

These results emphasize evidence that a minimally invasive myxoma resection via the right lateral minithoracotomy can be the ideal approach in myxoma resection, specifically in Colombia where open surgery is often chosen based on lack of expertise or equipment/ personnel available. We believe we can promote the use of this alternative surgical approach, especially in Colombia, given the promising results shown worldwide and locally.

\section{Conclusions}

Cardiac tumors are rare and often unrecognized until autopsies are performed, the most common type being the myxoma. Although the surgical approach is varied depending on the expertise, cost and equipment available, recently a minimally invasive myxoma resection via the right lateral minithoracotomy has been proposed as an ideal approach. We believe the case reports in this manuscript provide an idea for future surgical techniques as the patient outcomes are promising compared to open surgeries. We hope these excellent results promote further research in Colombia as well as increase education to ensure it becomes the norm.

\section{Funding}

The authors declare there was no funding provided for this report. 


\section{Conflict of interests}

The authors declare they have no conflict of interests.

\section{Ethical disclosures}

Protection of human and animal subjects. The authors declare that no experiments were performed on humans or animals for this study.

Confidentiality of data. The authors declare that they have followed the protocols of their work center on the publication of patient data.

Right to privacy and informed consent. The authors have obtained the written informed consent of the patients or subjects mentioned in the article. The corresponding author is in possession of this document.

\section{References}

1. Reynen K. Cardiac myxomas. N Engl J Med 1995;333(24):1610-1617. [PMID: 7477198 DOI: 10.1056/NEJM199512143332407].

2. Hoffmeier A, Sindermann JR, Scheld HH, Martens S. Cardiac tumors--diagnosis and surgical treatment. Dtsch Arztebl Int 2014;111(12):205-211. [PMID: 24717305 PMCID: PMC3983698 DOI: 10.3238/arztebl.2014.0205].

3. Jain S, Maleszewski JJ, Stephenson CR, Klarich KW. Current diagnosis and management of cardiac myxomas. Expert Rev Cardiovasc Ther 2015;13(4):369-375. [PMID: 25797902 DOI: 10.1586/14779072.2015.1024108].

4. Singhal $P$, Luk A, Rao V, Butany J. Molecular basis of cardiac myxomas. Int J Mol Sci 2014;15(1):1315-1337. [PMID: 24447924 PMCID: PMC3907871 DOI: 10.3390/ijms15011315].

5. Thyagarajan B, Kumar MP, Patel S, Agrawal A. Extracardiac manifestations of atrial myxomas. J Saudi Heart Assoc 2017;29(1):37-43. [PMID: 28127217 PMCID: PMC5247297 DOI: 10.1016/j. jsha.2016.07.003].

6. Mir IA, Ahangar AG. Atrial myxoma: a review. Int J Community Med Public Health 2016;3(1):23-29. [DOI: http://dx.doi.org/10.18203/23946040.ijcmph20151479].

7. Owais TA, Farber G, Garbade J, Mohr FW. Excision of a left atrial myxoma via a minimally-invasive technique: a possible routine access. Interact Cardiovasc Thorac Surg 2011;12(5):875-877. [PMID: 21138916 DOI: 10.1510/ icvts.2010.248492]. 